\title{
Enhancing ecological consciousness through liturgical acts of doxology and lament
}

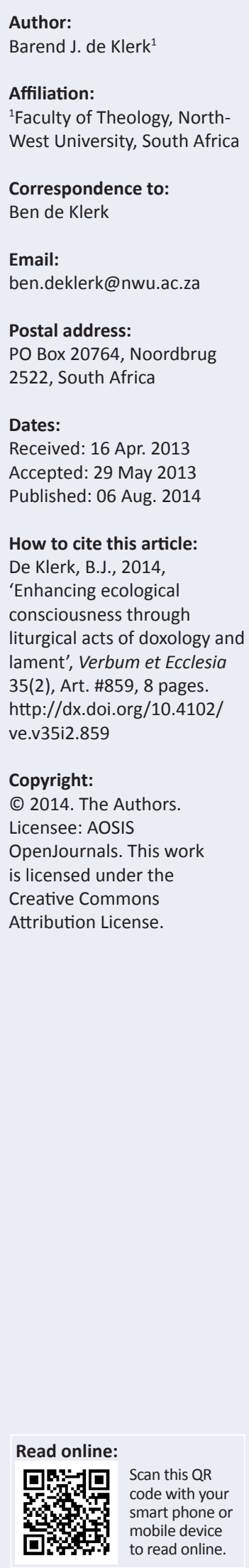

The last few decades have been a time of growing interest and concern about our environment. The extinction of plant and animal species, the pollution of our water supply and the depletion of critical resources have generated a new consciousness about our biosphere. The liturgy of the church must seriously engage with the ecological perspective, and the entire life, worship and praxis of the church should include an ecological dimension and vision. Two very powerful elements in enhancing worshippers' ecological consciousness are praise or doxology and the important counterpart of doxology, namely song and prayer of lament as well as confession of guilt. This means that believers celebrate the inalienable beauty and dignity of all living kind and bear witness to God's manifold creation. Believers are also to bear witness to creation's groaning as the ground suffers from deforestation, mountain-top removal, toxic dumping and rising temperatures. Comfort and new possibilities for rectifying the ecological crisis may develop from grief and lament. The liturgical witness will be that God's newness will break the cycles of self-destruction and make new life possible.

\section{Introduction}

In the last chapter of his book Die erediens as fees [The service as celebration], which was awarded with the Andrew Murray prize, Julian Müller (1990) focuses on the worship service and the world. He argues that the worship service must balance its vertical dimension (focused on God above) with its horizontal dimension (focused on the world outside). The worship service contains no closing but entails sending people into the world to continue the liturgy of life. If partakers in the worship service will keep this important double focus, it will not become worldly, but it will be earthly. A worship service must not be an escape from the world and in that sense aboveearth. There should be a healthy interaction between the worship service and the world (Müller 1990:107). The liturgy ought to consider the environment in which partakers are living, and in that sense, an ecological consciousness may enhance worship.

Following this book, Müller became well-known for his emphasis on the power of the narrative in Pastoral Studies. This method is also applicable to the narrative approach to liturgy (Bosman \& Müller 2009:2). The approach includes that liturgy may also be understood as the re-telling of a well-known narrative, the continuing construction of a new understanding of the well-known story, telling the past and dreaming a future, the dramatic narrative where symbolic and verbal communication are integrated (Bosman \& Müller 2009:2). This calls for a narrative approach to liturgy in which our stories, the earth's story and the story of the universe are located within God's story. We are invited and may invite others to dwell within the story of God's love for God's own creation. 'This is a story of God's creative, protective, nurturing and nourishing, hurt, enduring, corrective, salvific, innovative, vindictive and transformative love for creation' (Conradie 2005:342). In this way, the liturgical acts are focussed on God, and the world (earth) assists the congregation so that ecological consciousness awakens in them.

The problem statement of this article is: How can we integrate ecological consciousness into the practice of worship? To put it in other words: How can we enhance ecological consciousness through liturgical acts, especially the acts of lament and doxology? A short narrative pictures an example of the ecological trauma, after which the article describes a few theological perspectives on ecology. In the last section, the article deals with lament and doxology as liturgical acts.

\section{The story of Deepwater Horizon rig}

In the spring and summer of 2010 the world watched an ecological catastrophe unfold in the Gulf of Mexico. On 20 April 2010, the Deepwater Horizon rig, located roughly 41 miles off the coast of Louisiana, exploded (Hessel-Robinson 2012:40). The Deepwater Horizon oil spill (also referred to as the British Petroleum [BP] oil spill, the BP oil disaster, the Gulf of Mexico oil spill and the Macondo blowout) was an oil spill in the Gulf of Mexico on the BP-operated Macondo Prospect, 
considered the largest accidental marine oil spill in the history of the petroleum industry. Following the explosion and sinking of the Deepwater Horizon oil rig, which claimed 11 lives, a sea-floor oil gusher flowed unabated for 3 months during 2010 (Damien 2012). The gushing wellhead was not capped for 87 days, until 15 July 2010. The total discharge is estimated at 4.9 million barrels (210 million US gallons; $780000 \mathrm{~m}^{3}$ ). A massive response ensued to protect beaches, wetlands and estuaries from the spreading oil, using skimmer ships, floating boom, controlled burns and 1.84 million US gallons $\left(7000 \mathrm{~m}^{3}\right)$ of Corexitoil dispersant. After several failed efforts to contain the flow, the well was capped and declared sealed on 19 September 2010. However, the months of spill, along with response and clean-up activities, caused extensive damage to marine and wildlife habitats and to the Gulf's fishing and tourism industries. It also caused human health problems. Environmental and health consequences are continuing, as is study and investigation. Some reports indicate that the well site may still be leaking (Biello 2010).

Thick black ooze formed pools on the water's surface, coated marshes, fouled wildlife habitat, washed up on beaches and closed fisheries. The consequences were enormous. In addition to the human lives lost, the death toll included thousands of birds, hundreds or more marine mammals, hundreds of sea turtles and untold numbers of fish, crustaceans and other sea creatures (Nelson 2011). The full costs of the Deepwater Horizon disaster may not be known for years to come, but it was a disruptive, calamitous event in the human and ecological life of the Gulf of Mexico (HesselRobinson 2012:40).

The greatest impact was on marine species. The spill area hosted 8332 species, including more than 1200 of fish, 200 of birds, 1400 of molluscs, 1500 of crustaceans, 4 of sea turtles and 29 of marine mammals (Biello 2010). In the first birthing season for dolphins after the spill, dead baby dolphins washed up along the Mississippi and Alabama shorelines at about 10 times the normal rate. Oil was discovered on dead dolphins along the Gulf Coast (Nelson 2011). Research suggests that as much as one-third of the oil remains in the Gulf (Damien 2012).

\section{The narrative of humankind, the earth and liturgy}

There is also the Biblical narrative. This narrative highlights the integral relationship between humankind and our environment from its very beginning. In Genesis 1:28, God states:

Be fruitful and increase in number; fill the earth and subdue it. Rule over the fish of the sea and the birds of air and over every living creature that moves on the ground.

Genesis 2:7 explains: 'The LORD God formed the man from the dust of the ground and breathed into his nostrils the breath of life, and the man became a living being' (New International Version [NIV]). Human beings are born of the earth and are constituted from the same matter that constitutes the earth.
Like the earth itself, we are carbon-based life forms. Ecology can be defined as the relationship between living organisms and their environment (Johnson 2012:31). Human beings cannot exist except within an ecological-environmental setting (Johnson 2012:31).

The complementary nature of liturgy and ecology is also considerable. The English word worship is derived from the old English worth-ship, indicating the liturgical practice of ascribing worth, firstly, ultimately, to God but then also to events in history, ancestors in faith, water and bread and wine, even sparrows and the hairs of the human head and the whole creation itself, which has its worth liturgically proclaimed by the word of God as 'very good' (Steward 2012:1). The basic act of worship extends toward the horizon of the creation, to things seen and unseen, to ascribe worth to God. Ecology, too, by definition, extends to the horizons of the universe. The discipline of ecology explores the interdependence of everything, especially as these relationships come to expression in the abundant life of planet earth (Steward 2012:1). The flourishing of life on earth is considered a good - even a 'very good' - of this academic discipline. Thus 'liturgy and ecology both approach the cosmos by extending outward toward the farthest horizons, ascribing inherent worth to the creation, and seeking creation's flourishing and abundant life' (Steward 2012:1). In this respect, two important aspects of liturgy, namely lament and doxology, will be the focus of this article, especially the enhancement of ecological consciousness through lament and doxology.

\section{A new awareness of the devastation and restoration of nature}

The last few decades have been a time of growing interest and concern about our environment. The extinction of plant and animal species, the pollution of our water supply and the depletion of critical resources have generated a new consciousness about our biosphere. The releasing of toxic waste into the environment by industry and agriculture undoubtedly has had an adverse effect on the environment, particularly on humans. We share the earth and the resources of the earth with people and living creatures all over the world. Through the image of the global village, we can see that, because of modern means of communication and transport, we are all neighbours as in a traditional village. Communication creates communion with no regard for traditional boundaries and distances. Cell phones, the Internet, email and other forms of electronic communication enable us to communicate with each other with almost no delay at all. Individuals in different nations can be closer than ever before. Air travel bridges vast distances. We are beginning to share one space, time delays are vanishing, physical distance is shrinking and interdependencies are growing. Thus, says Moltmann (2011):

Our lives are more and more tightly intertwined. Events in Europe have consequences in Africa; changes in China affect us all; the collapse of the US real estate market brought the finances of many nations to their knees. (p. 16) 
Moltmann (2011) stresses the fact that the earth is the victim in the age of globalisation:

The different peoples of the world are merging into one humanity. Different cultural traditions are melding together. The economy is globalizing markets and production systems. Wealth and poverty are being globalized by the banks. Just as in a traditional village, we are all related, and we all share in the sorrows and joys of our common life. There is one partner in this process that has not yet had its say, for almost nobody listens to its voice. That is the earth, our common home and the source of all life. We globalize our civilization with no concern for the strengths and weaknesses of the globe itself. We globalize our human economy at the expense of the earth's resources. Every year, thousands of species become extinct; the climate deteriorates; the deserts expand; the sea level rises. (p. 17)

If we fail to bring the earth and its glory and sorrow into our liturgy and if we as part of the human race continue the trend to force the earth to bear fruit constantly, using artificial fertilizers, we will exhaust the ground and make it infertile. The deserts will spread, droughts will become more frequent and eventually the human race will disappear from the earth that it has wrecked and abused. The extinction of plant and animal species, the pollution of our water supply and the depletion of critical resources have generated in some societies a new consciousness about our biosphere. As environmental conditions change throughout the world, less arable land results in shortages of basic foods like rice and grains. When this shortage is coupled with higher oil prices, we find that millions - if not billions - of our fellow human beings are starving as food prices skyrocket. 'If we continue on our current trajectory, the bodies of many of our human and non-human counterparts may soon be broken beyond repair' (Galbraith 2009:294). Poverty is one of the causes of environmental degradation in Africa. Hand in hand with poverty comes the HIV and AIDS pandemic which is currently threatening the socio-economic survival of the continent. Indeed, sick people cannot take care of their environment since human health is a critical component of ecological solidarity (Conradie 2005:331).

As rational beings, born with intellect, imagination, will, and freedom, humans have a responsibility to care for the earth that is our home, our sustenance, our place of existence and the venue God has ordained for the living of our lives. If human beings could become more aware of the seemingly inseparable relationship between them and the earth and the common destiny they share, the modern view of seeing earth as only a commodity to be consumed can be reviewed in favour of the entire creation (Hallman 1994:70). In my opinion, it is especially the calling of the church in the worship gathering and in the worship of everyday life to testify about this relationship between believers and the earth. In empirical research that asked the question, 'Is the creation being celebrated in worship services?', the answer was negative (Harries 2011:22-25; see also the opinion of Buitendag 2005:67). The redemption of creation comprises the heart of the church's contribution to the great work of our time, the seismic shift away from a suicidal and sinful relationship with the ecosystems on which our lives depend toward a restored and flourishing, nourishing life in the triune God's created abundance for all (Dahill 2012:5).

The environment is God's gift to everyone, and in our use of it, we have a responsibility towards the poor, towards future generations and towards humanity as a whole. In the Old Testament, the narrative and celebration of the Sabbath year taught that the people of Israel had to leave the land every 7th year to fallow. Two reasons are given: 'so that the poor of your people may eat' (Ex 23:10) and so that there may be 'a Sabbath of complete rest for the land' (Lv 25:4). Sabbath rest for the earth is blessed by God, for this year allows the land to become fruitful again. Okonkwo (2011) points out:

The Church in her liturgy has a responsibility towards creation and she asserts this responsibility in the public sphere. In so doing, she must defend not only earth, water and air as gifts of the creation of God that belong to everyone. She must above all protect mankind from self-destruction. (p. 44)

If the church of Christ wants to reach 'the ends of the earth' (Ac 1:8), she must turn back to the earth and give back the beauties and virtues that she has projected onto the world beyond. The liturgy of the church must seriously engage with the ecological perspective and start by applying it to her. Should the earth no longer be able to support life, it would mean the end of the human world and the end of the church and her worship (Moltmann 2011:24).

\section{Theological flaws lead to one- sidedness in worship}

There is more than one theological viewpoint that may lead to a lack of ecological consciousness in the practice of liturgical acts in the worship service and in the liturgy of life. The most important theological flaws are mentioned below:

- There is an overemphasis on divine transcendence that strips God of his connection with the world. Moltmann (1985:13) suggests that there is a need to recognise God's presence in the world (and, as he adds, the presence of the world in God).

- There is a one-sided bias in the Christian vision of redemption. Too many Christians remain ignorant of the fundamental connection between the Christian vision of redemption and the life of earth itself. Too often, Christians speak and act as if the meaning of Jesus' incarnation, death and resurrection is limited to the salvation of individual believers alone, often imagined as taking place in an afterlife beyond this created world. Even when the Christian message includes attention to God's desire in Christ for just and peaceful human community, it often still remains detached from explicit attention to the biological systems on which our lives depend and from the beauty and integrity of the creation itself. This relative detachment of the Christian witness from the life and care of creation is visible in the church's worship, the most important symbolic public witness to the shape of our faith, hope and love (Dahill 2012:3).

- There is sometimes a misconception that Christ is only the head of the church. Rather, the Risen One is the Lord 
of both creation and the church; in him and through the shedding of his blood, the human family and the whole of creation are renewed and given peace (Power 2010:306).

- There is a possibility of a lopsided anthropology. Though a genuine environmental theology needs an anthropology that reclaims the dignity of human life, care should be taken to see that such a venture does not give humans an inordinate right to dominate creatures and lavish the resources of the earth for themselves alone. Williams (2009:1) sees this as humanity that has a 'priestly' relationship with the natural order: The human agent has been created with the capacity to make sense of the environment and to move it into a closer relation with its creator by drawing out of it its capacity to become a sign of love and generosity. A responsible anthropology is an anthropology that sees and projects human beings as united with God and the rest of creation in a wonderful balance.

An ecological reformation of Christian theology and liturgy implies that these flaws can be corrected. 'Reformation is not something alien to the Christian faith, as the protestant axiom of ecclesia reformata semper reformanda indicates' (Conradie 2012:189). Ecological theology and ecological liturgy are therefore an attempt to retrieve the ecological wisdom in theology as a response to environmental threats and injustices (lament). At the same time, it is also an attempt to reinvestigate, rediscover, reform and renew theology in the light of the challenges posed by the environmental crisis, especially in the acts of praise (doxology). There is a clear need for a thorough reintegration of the doctrines of creation, sin, providence, redemption and consummation. The narrative of God's love for the world will lose its plausibility whenever these aspects are allowed to become disintegrated from one another (Conradie 2005:300). The entire life, worship and praxis of the church should include an ecological dimension and vision.

Conradie (2005) emphasises the importance of using all senses and also the body to express the ecological dimension in liturgy:

Because of its rejection of the rich symbolism of mediaeval worship, Protestantism became solely a religion of the ear, neglecting not only the other senses as media of divine communion, but the body itself as temple of God. The ecological challenge reawakens us to the ways our bodies make us a part of nature, the wider temple of God's creativity. How we move our bodies, how we breathe, what we drink and eat, what we do with our waste-all these are relevant to the symbolic expression of our relationships with God, with other humans, with other creatures, and with the earth. By opening up to symbols beyond the verbal and intellectual we make possible this expansion of the ecology of worship. Worship moves from being a school to being something more like a theatre. (p. 325)

In the African traditional world view, the well-being of man is intimately connected with the well-being of the total creation. If man abuses nature or the environment, nature also will abuse man (Okonkwo 2011:38). Even Asian and African spirituality and worship may be characterised as friendly and open to the environment and the cosmos whereas Western-dominated theology may be characterised as patriarchal and aggressive towards nature, attitudes that may be the main reason for the present ecological crisis (Van't Spijker 1994:90).

\section{The power of the liturgical acts of lament and doxology}

In my opinion, two very powerful elements in enhancing worshippers' ecological consciousness are praise and doxology and the important counterpart of doxology namely song and prayer of lament. These acts show that participants in the worship service are part and parcel of the world in which they live, a broken world that mourns the devastating results of exploiting the environment. Worshippers are, however, also part of the beauty of this world and of God's new world that is breaking through at the present time. This is the dialectic character of liturgy, namely criticising and energising (Brueggemann 2001):

... criticizing through the hymn of lament on the broken context they are living in, and at the same time energizing through songs of hope on the vision of a reformed present world and the new world to come. (p. 115)

The liturgical criticising should be done with pathos (especially by uttering groans and laments) and the energising with amazement (through doxologies).

Worshippers should attain a different perspective on caring for the earth. They must call upon people to abandon the status quo, imposed by those who would profit most from it (Junler 2011:136). In the liturgical prayers, we may name the destruction of our planet and identify the infidelities that make our common life toxic (Brueggemann 2011:38). Liturgy is also the enactment of hope in contexts of loss and grief. It is the declaration that God can enact a novum in our very midst, even when we judge that to be impossible. 'When the denial of guilt and grief and loss has been penetrated, the liturgy has a new task. It may move through judgment and grief to hope-filled possibility' (Brueggemann 2011:110). In the face of radical and continuing evil concerning the environment, liturgical acts must include weeping. It must be confession, but it must also be resistance. Resistance is not just our reaction to the evil we experience and in which we participate, but it is our stand against it. It is not an act of standing still and defending ourselves against the evil that surrounds us, but it is moving into it and through it with speech and presence and action (Smith 1992:5).

To see the world as creation is to recommit ourselves to its care, not as the fittest, most powerful creatures on the animal planet but as a species held uniquely responsible for the planet's flourishing. It is to celebrate the inalienable beauty and dignity of all living kind and to bear witness to God's manifold creation. It is also to bear witness to creation's groaning as the ground suffers from deforestation, mountaintop removal, toxic dumping and rising temperatures: 
To see the world as God's intricate, intelligible, surprising, sustainable creation is to return to wonder and to go forth in wisdom, such that 'mountains and the hills ... shall burst into song and all the trees of the field shall clap their hands (Is. 55:12). (Berry 2012:184)

\section{Lament}

How do shattering events like the Deepwater Horizon catastrophe resonate liturgically? That is, how can the anger, grief, fear and shame evoked by the oil spill and all the threats to creation that it represents be expressed? Mainly through lament, claims Hessel-Robinson (2012:40).

Lament is disorienting: It raises troubling questions. How can a faithful God whose mercy fills the cosmos allow such devastation? Does the God of creation not hear the cry of the parched earth and of each dying species? Has God forgotten the suffering poor who bear a disproportionate share of the misery? Why are those who profess belief so blind and deaf to the destruction of God's precious community of life (McGann 2012:55)? Where do we find opportunities to wrestle with the meaning of ecological destruction for our sense of human vocation and the presence (or absence) of God in worship? Are there resources that Christian communities can draw upon to help us articulate our experience of ecosystemic ruin in God's presence (Hessel-Robinson 2012:41)?

One answer to these questions is found in the practice of lament. The biblical tradition of lamentation offers contemporary worshipers models of how Israel and early Christians responded to personal and social calamity by engaging with God in a dialogic practice of complaint, protest, rage and mourning (Grant 2011:190). These biblical prayers of 'pain and protest', as recent scholars termed them, demonstrate how ancient people candidly expressed their anger and their disappointment with God to him when faced with crushing circumstances. Such prayers helped worshipers confront the reality of their situation and enacted a process of hope and healing in dialogue with God (Hessel-Robinson 2012:41). 'Anger toward God can occur following any kind of suffering, particularly when the individual perceives the suffering as unfair' (Snow et al. 2011:31). In this phase, we learn the more difficult modes of Christian worship: deep lament, heartfelt intercession, truthful confession of personal and communal culpability and practices of repentance and change of heart (McGann 2012:54).

To commit a crime against the natural world is a sin. For human beings to cause species to become extinct and destroy the biological diversity of God's creation, to degrade the integrity of the earth by causing climate change, to strip the earth of its natural forests or to destroy its wetlands, to contaminate the earth's waters, its land, its air, and its life - all of these are sins (Chryssavgis 2010:215). Cilliers (2009) adds his voice in this regard:

Lament can entail a personal confession of sin or flow from experiences of vulnerability - then the cry, often articulated in liturgical tradition as kyrie eleison (Lord, have mercy on us) is intended to evoke God's grace and compassion. But lament can and should also take place with a view to the sufferings of the world. It is systemic and vicarious in nature. (p. 40)

When environmental calamities like Deepwater Horizon occur, and in light of the threats facing earth's ecosystems, Christian liturgy must develop and incorporate prayers of lament in order to help worshipers express their experiences of loss, grief, anger and fear in relation to ecological destruction, which is also a personal and social calamity (Grant 2011:198). Recovering the practice of lamentation is a way to start coming to terms with current ecological realities and to envision human participation with God in the healing of the earth (Bjorlin 2012:35).

In lament, the congregation declares its guilt in the light of, and as opposed to, the majesty of God. It would seem as if lament has to a large extent been lost or neglected in contemporary worship services for a number of reasons, such as the influence of a success-driven society in which there can be no place for frailty or vulnerability. The lack of lament can also be due to certain God-images that dominate our theology and liturgy or specific understandings of soteriology that reduce lament to the confession of individual sin only, as Cilliers (2007) claims:

Perhaps it could also be said that the loss of lament is connected to a loss of a liturgy of silence and awe. This loss of a liturgy of silence and awe could be the result of an ignorance of the importance of the approach to God. (p. 161)

Lament is critical to liturgy that is honest. Confession is necessary for truthful worship. Yet too often, we suppress these difficult modes of prayer, afraid to admit the cries of the earth and its suffering people into our sacred gatherings, unwilling to own our complicity in the exploitation of the earth's resources (McGann 2012:55). When we exclude lamentation from our prayer, we lose a vital resource for coming to terms with potentially shattering experiences and for the formation of hope. When we do not make room in worship to contend with God about the realities of destruction and suffering in the world, our only recourse is to endure things passively as they are (Hessel-Robinson 2012:44).

Lament names that which threatens creation's goodness and integrity. Responding to current ecological realities requires naming them honestly and precisely (Brueggemann 1997:97). Lament offers a form that helps us to express the grief, fear, anger and sense of loss we feel in light of ecological destruction. Shattering experiences or realisations often result in traumatised silence. Silence becomes a survival strategy in dealing with the experience of suffering and feelings of hopelessness. There are few resources for expressing that which seems beyond speech. 'Lament offers language and structure through which we can bring our wordless despair to expression. Lament becomes the formfullness of grief' (Brueggemann 2010:112).

Without disorientation, without struggling with God, without examining our own lives, our faith remains inadequate to our experience. We cling to a false security, forget God's 
presence in suffering and, most importantly, undermine our own co-responsibility, with God, for the care of the earth (McGann 2012:55). Brueggemann (2002:45) argues that one of the functions of lament is to 'evoke reality for someone who has engaged in self-deception and still imagines and pretends that life is well-ordered'. Lament must give voice to the victims so that their cries reach our ears and hearts. Many of earth's creatures face impending destruction, and peoples around the globe suffer immensely from the devastation of the natural resources on which they depend. Confession must acknowledge our collusion and inaction in the face of their anguish. Intercession must cry out for wisdom and grace to embrace the way of the suffering Christ. Repentance must acknowledge that we have grieved the Holy Spirit of life and must lead us towards acts of restorative justice, towards works of mercy and healing and towards solidarity with all who are deprived of their intrinsic right to life and well-being (McGann 2012:55).

In situations where all language has been shattered by suffering, the prayer of lament becomes a speech-enabling gift of God. Lament helps us to identify with other creatures who suffer. 'A common thread running through much contemporary ecotheology is that all things share a common evolutionary history; thus all things are a part of an interconnected, interdependent whole' (Hessel-Robinson 2012:45). A lament typically begins with a cry to God for help. Some unspecified evil, enemy or disease threatens the people who are praying, and they have turned to God for deliverance (Bosman \& Müller 2009:15). Despite the frequency and intensity of the prayer, however, the one praying often complains that God is not listening, that God delays in answering. Nonetheless, the one praying remains certain of God's love and confident of God's ultimate intervention. Despite the psalmist's tenuous situation and God's seeming inattention, the lament always concludes with an expression of trust in God. We see this progression from pain and complaint to praise and confidence, for example, in Psalm 13 (Harmon 2011:52).

By incorporating prayers of lament for suffering wildlife, extinct and endangered species, polluted air, water, and land and the negative impact of climate change, Christian worship can begin to help its participants confront current ecological realities honestly. It helps them to name a sense of loss and fear, admit the difficult questions that arise about divine power and human vocation and begin to live into a different future. The concerns people carry with them need to be invited into the assembly so that we can begin to process them in the presence of God and begin to imagine ways to participate in a different and more hopeful future. The work of lament does not end at the church doors, but it invites those who lament to move from despair and silent fear to a renewed and spirited commitment to join the Creator in the work of restoring a damaged creation (Hessel-Robinson 2012:47).

Once we experience the whole creation as alive and are drawn in praise toward the One whose creating word sustains it, we can acknowledge our complicity in earth's destruction. We can learn to lament with earth's creatures in their suffering, to confess our misuse of God's bounty and to embrace a path of repentance and change of heart. Conversion empowers us to embrace new patterns: a deeper commitment to healing the earth and to rediscovering worship's creational and cosmological vitality (McGann 2012:50).

\section{Doxology}

Is creation really celebrated in worship (Harries 2011:23)? Are there resources in our liturgical traditions that can awaken us anew to the beauty and wonder of creation but also to the ways that humans injure it? How can liturgy form us, spiritually and morally, to live in ways that honour the earth? Have we lost the art of awe? Awe forms the backbone of liturgy, claims Cilliers (2009):

If a liturgist and congregation lose the art of awe, or have never learned it, it would be better for both liturgist and congregation to abandon the enterprise called worship. (p. 39)

We call this crisis 'ecological', which is fair insofar as its results are manifest in the ecological sphere. Yet, the crisis is not first of all about ecology. It is a crisis about us. It is a crisis about the way we envisage and imagine our world (Chryssavgis 2010:219). In my opinion, the ecological invitation here is to see all created life in new ways, to experience earth in its amazing complexity and interdependence and to discover our participation in the dynamic unfolding of a universe. Earth's biodiversity invites us to come to know the web of life from within, to discover a bond with each creature, to expand our capacity to grasp the world in its interrelatedness and to acknowledge our dependence on thousands of species. We come to know life in its fullness when we enter more deeply into a relationship with ourselves, with other humans and with the ecosystems in which we live when we discover our kinship with every strand of the web of life. 'Such intimate knowledge of the community of creation bids us ask: what must the divine Creator be like, out of whose heart this amazing universe has been created?' (McGann 2012:51).

Each creature in the web of life is a symbol of God's presence; each is embraced by God and called into God's redemptive future. In Christ, God entered evolving creation in a profoundly new way: The Incarnate One, Word-becomeflesh, became an earth creature, sharing biological life with others on this planet. The risen Christ has assumed a cosmic role, leading creation back into God in a great act of love and thanksgiving that will be realised in its fullness in the great eschaton. Each creature, each dynamic ecosystem is a reflection of God, a spark of divine life, a revelation of divine goodness and beauty. Loss of biodiversity is, hence, not only an impoverishment to human life but an affront to God who created all beings in infinite love and invites each creature to participate in divine life. The splendour of nature, from its immense landscapes to its microscopic particles, invites us to praise-filled worship (McGann 2012:52).

In its own distinctive way, the earth unites us all: beyond any individual or collective efforts and certainly beyond 
any doctrinal or racial differences. We may or may not share religious convictions or political principles, but we do share an experience of the environment. We share the air that we breathe, the water that we drink and the ground that we tread - albeit neither always equally nor always fairly. 'By some mysterious connection that we do not always understand (and sometimes choose to ignore), the Earth itself reminds us of our interconnectedness' (Chryssavgis 2010:215). Creation may surprise us with its beauty, originality or timeliness. Being creations of God with feet planted on the ground and spirits that transcend the earth is our common blessing, as Sledge (2005) argues:

Creation sends messages without words in thousands of small ways. Its voice is in the cry of the hawk, the rush of a mountain stream, the bleating of a lamb, the clap of thunder. Its face is in the cleft of a rock, the bark of a tree, the design of a sunflower's petals around the seeds, the light of a firefly, the intense gaze of an owl. (p. 66)

Delighting in life's dynamic web and discovering God's Spirit alive within call us to rediscover our corporate ways of worship in concert with creation's praise of God.

The language of our rites must come alive with images of the vastness and magnificence of creation that can awaken our religious imagination to God's work in the universe. McGann (2012) phrases it eloquently:

The truthfulness of our preaching and prayer must speak of creation in ways that are attuned to scientific discoveries of the unfolding of the universe, that acknowledge our interdependence with every form of natural being, and that honestly address the degradation brought about by human avarice. (p. 57)

What seems to be a harmless omission of hymn texts honouring the earth is possibly harming the church's view concerning the world in which we presently live. At least part of the function of music in our churches has been to actively sing ourselves off the earth, purposely seeking to escape this home for another (Witt 2012:17). At best, this world-denying repertoire has been a diversion. At worst, it has been a drug numbing us to the importance of God's work and our work alongside God and the rest of creation (Witt 2012:18). 'We need to be freed from our conviction that God can only be praised through and amidst an avalanche of words. Tibi silentium laus - Lord, to you silence is praise' (Cilliers 2008:28, 29). Cilliers (2009) also claims:

We become silent and filled with awe, because God is the majestic and totally different God; but we are also brought to silence and awe with the knowledge that God's revelation is one of grace and compassion, that God is close by, closer than our dress or shirt (Luther). (p. 42)

Sledge (2005) quotes the song in which St. Francis of Assisi invites all creation to join the chorus (the first stanza):

All creatures of our God and King,

lift up your voice and with us sing:

Alleluia, Alleluia!

O burning sun with golden beam,

O silver moon with softer gleam,

O praise God, O praise God,

Alleluia, Alleluia, Alleluia! (p. 72)
Ironically, if we are honest about the task that lies before us, then the earth, too, will celebrate; the earth, too, will cooperate. God's world has incredible healing powers. Within a single generation, we could steer the earth toward our children's future. Let that generation start now:

Liturgy, then, is precisely a commemoration of this innate connection between God and people and things. It is a celebration of communion, a dance of life. The world in its entirety comprises an integral part of the liturgy. God is praised by trees and birds, glorified by the stars and moon (Ps. 8:3), worshipped by sea and sand. (Chryssavgis 2010:217)

\section{Lament and doxology}

Only from pathos, grief and lament, and in some cases judgement as the deepest turning point, a longing may develop for an alternative. Comfort and new possibilities for rectifying the ecological crisis may develop from grief and lament. The liturgical witness will be that God's newness will break the cycles of self-destruction and make new life possible. Hope is grounded in God's promises, and his promises bring amazement and lead to doxology. Energising is initiated when the liturgy points out the possibilities of hope, and hope is roused by amazement about God and his great deed of regeneration, especially in the death and resurrection of Christ.

'Lament is of paramount importance, but it is never an end in itself. The language of hope and the language of lament are flipsides of the same coin' (Cilliers 2007:159). Without the 'counterbalance' of lament, praise becomes 'smug satisfaction', or vice versa, lament can be misunderstood as a perpetual denial of grace. There is a fundamental tension between lament and praising in liturgy because God has reaffirmed our identity through grace. This juxtaposition of lament and praise plants the liturgy firmly within the realities of life but also within the reality of God's Kingdom - the latter being understood in an eschatological manner, which means that we celebrate the reality of this Kingdom as one that has come, is coming and therefore is present. We face so many realities that seem to contradict the reality of God's Kingdom every day, and as a result, we enter into God's presence and approach God with lament. God's response to our lament is one of affirmation and indeed re-affirmation. In approaching God with lament, we are (re)affirmed and formed as the forgiven and liberated people of God. In approaching God, we are reminded of our vulnerability (and the suffering of the world) but also of our identity in Christ (and there-fore our hope for the world) (Cilliers 2009:42).

\section{Conclusion}

Loving the earth is the starting point: Falling in love with its complex, extravagant human-non-human web of life is a necessary spiritual foundation for grappling with its contemporary devastation. Once the heart is awakened, our compassion grows.

A new vision, a new story, must take hold, one that offers us fresh metaphors and images for humanity's relationship 
with the rest of the earth community: with soil, water, air and all living creatures. From the beginning of time, the Creator Spirit of God has moved in this world, establishing patterns that are intrinsic to life itself. To be converted to a sustainable future for the earth community is to cooperate with this divine Spirit, to be drawn into the Spirit's compassionate power and wisdom at work in the world, preserving and restoring the integrity of earth's systems.

God's future is already at work in the world, and we are invited to engage with God in the work of healing and regeneration until the final transformation of all things in Christ when God will 'be all in all' (1 Cor 15:28, New Revised Standard Version [NRSV]). Christian worship is an act of anamnesis, a memorial and thank-offering for God's magnificent acts in both creation and redemption in Christ. A contemporary creational consciousness calls us to redress the historical imbalance that has focused worship primarily on redemption with little emphasis on creation and to restore the reciprocity of these profoundly connected acts of God. Every aspect of liturgy must be permeated with a sense that our earthly home is a locus of God's activity and that we, together with all created beings, constitute a communion of subjects in God's presence.

\section{Acknowledgements Competing interests}

The author declares that he has no financial or personal relationship(s) that may have inappropriately influenced him in writing this article.

\section{References}

Berry, R.J., 2012, 'Creation care: Stewardship or what?', Science \& Christian Belief 24(2), 169-185.

Biello, D., 2010, 'The BP spill's growing toll on the sea life of the gulf', 09 June, Interview, Yale Environment 360, Yale School of Forestry \& Environmental Studies, United Stated.

Bjorlin, D., 2012, 'The courage to lament: An analysis of mainline hymnody', Liturgy 27(1), 28-37. http://dx.doi.org/10.1080/0458063X.2011.615273

Bosman, L. \& Müller, J., 2009, "n Narratiewe benadering tot die liturgie', Verbum et Ecclesia 30(2), 6 pages. http://dx.doi.org/10.4102/ve.v30i2.179

Brueggemann, W., 1997, Theology of the Old Testament: Testimony, dispute, advocacy, Fortress Press, Minneapolis.

Brueggemann, W., 2001, Prophetic imagination, Fortress Press, Minneapolis. Brueggemann, W., 2002, The spirituality of the Psalms, Fortress Press, Minneapolis.

Brueggemann, W., 2010, 'Risking truth: Reshaping the world through prayers of lament', Journal of Biblical and Pneumatological Research 2, 110-116.

Brueggemann, W., 2011, The practice of prophetic imagination: Preaching an emancipating word, Fortress, Augsburg, Kindle Edition.

Buitendag, J., 2005, 'Liturgie as fontein van die lewe: 'n Oorsigartikel oor die kosmiese kartering van Gordon W Lathrop se boek, Holy ground: A liturgical cosmology', HTS Teologiese/Theological Studies 61(1\&2), 65-79.
Chryssavgis, J., 2010, 'A new heaven and a new earth: Orthodox theology and an ecological world view', The Ecumenical Review 62(2), 214-222. http://dx.doi. org/10.1111/j.1758-6623.2010.00059.x

Cilliers, J.H., 2007, Preaching as language of hope in a context of HIV and AIDS, Protea Book House, Pretoria. (Preaching as a language of hope: Studia Homiletica, 6).

Cilliers, J.H., 2008, 'Silence is golden: Liturgy beyond the edge of language', Praktiese Teologie in Suid-Afrika 23(1), 19-35.

Cilliers, J.H., 2009, “"Mysterium tremendum et fascinans": Liturgical perspectives on the approach to God', In die Skriflig 43(1), 31-44. http://dx.doi.org/10.4102/ids. v43i1.213

Conradie, E.M., 2005, 'Towards an agenda for ecological theology: An intercontinental dialogue', Ecotheology 10(3), 281-343. http://dx.doi.org/10.1558/ecot.2005.10.3.281

Conradie, E.M., 2012, 'Ecumenical discourse on pneumatology and ecology', Journal of Reformed Theology 6, 189-194. http://dx.doi.org/10.1163/15697312-12341269

Dahill, L.E., 2012, 'New creation: The revised common lectionary and the earth's paschal life', Liturgy 27(2), 3-16. http://dx.doi.org/10.1080/045806 3X.2012.637472

Damien, G., 2012, 'How attempts to clear up the Deepwater Horizon spill may have made it worse: Dispersant chemicals "made oil penetrate Gulf Coast beaches more deeply"', Daily Mail, 03 February, p. 9.

Galbraith, K.L., 2009, 'Broken bodies of God: The Christian eucharist as a locus for ecological reflection', Worldviews 13, 283-304. http://dx.doi.org/10.1163/13635 2409X12535203555759

Grant, J.A., 2011, The hermeneutics of humanity: Reflections on the human origin of the laments, T \& T Clark, New York.

Hallman, H.G., 1994, Ecotheology: Voices from South and North, Orbis, Maryknoll, NY.

Harmon, K., 2011, 'Growing in our understanding of the Psalms, Part 2: Persisting in prayer when God is silent', Liturgical Ministry 2, 52-54.

Harries, T.D., 2011, 'Faith and environmental impact: Congregations learn about, celebrate, and care for creation', Congregations 2, 22-25.

Hessel-Robinson, T., 2012, “"The fish of the sea perish": Lamenting ecological ruin', Liturgy 27(2), 40-48. http://dx.doi.org/10.1080/0458063X.2012.638789

Johnson, C.V., 2012, 'Embracing local ecology in liturgical expression', Liturgy 27(2), 31-39. http://dx.doi.org/10.1080/0458063X.2012.638788

Junler, T.B., 2011, 'Foundational concepts for prophetic liturgical praxis', Encounter 72(1), 133-144.

McGann, M.E., 2012, 'Making vital connections: Developing creational consciousness in life and worship', Liturgy 27(2), 49-61. http://dx.doi.org/10.1080/045806 $3 X .2012 .638793$

Moltmann, J., 1985, God in creation: An ecological doctrine of creation, SCM Press, London.

Moltmann, J., 2011, 'A common earth religion: World religions from an ecological perspective', The Ecumenical Review 63(1), 16-24. http://dx.doi.org/10.1111/ j.1758-6623.2010.00089.x

Müller, J., 1990, Die erediens as fees, NG Kerk-boekhandel, Pretoria.

Nelson, K., 2011, 'Spike reported in number of stillborn dolphins on coast', SunHerald. com., 14 February, p. 5.

Okonkwo, I., 2011, 'Ecological crises: From the perspective of Christianity and African traditional religion', Journal of Theology for Southern Africa 141, 32-44.

Power, D.N., 2010, 'Worship and ecology', Worship 84(4), 290-308.

Sledge, S., 2005, “'All nature sings": Creation and congregations worshiping God', Review and Expositor 102, 65-84.

Smith, C.M., 1992, Preaching as weeping, confession, and resistance: Radical responses to radical evil, John Knox Press, Louisville.

Snow, K.N., McMinn, M.R., Bufford, R.K. \& Brendlinger, I.A., 2011, 'Resolving anger toward God: Lament as an avenue toward attachment', Journal of Psychology and Theology 39(2), 130-142.

Steward, B.M., 2012, 'Liturgy and ecology: Introduction', Liturgy 7(2), 1-2. http:// dx.doi.org/10.1080/0458063X.2012.638785

Van't Spijker, G., 1994, 'Man's kinship with nature: African reflection on creation', Exchange 32(2), 89-148.

Williams, R., 2009, 'Renewing the face of the earth', Vocation for Justice 23(2), 1-5.

Witt, T., 2012, 'Singing with the earth and the global church', Liturgy 27(2), 17-30. http://dx.doi.org/10.1080/0458063X.2012.638787 